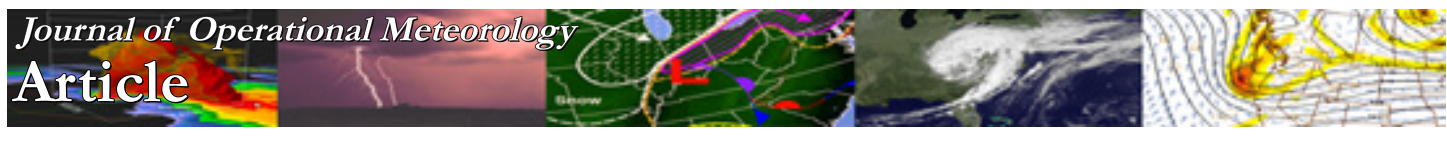

\title{
Thunderstorm Environments over the Northeastern Pacific Ocean and Gulf of Alaska
}

\author{
JONATHAN M. GARNER \\ National Weather Service, Juneau, AK
}

(Manuscript received 19 September 2016; review completed 9 February 2017)

\begin{abstract}
Thunderstorm environments over the northeastern Pacific Ocean and Gulf of Alaska were analyzed from the summer of 2014 through the early spring of 2016. Thermodynamic parameters investigated in this study highlight processes supporting charge separation in the 0 to $-20^{\circ} \mathrm{C}\left(32\right.$ to $\left.-4^{\circ} \mathrm{F}\right)$ layer $(\mathrm{CRTZ}$; charge reversal temperature zone), similar to the study carried out by Bright et al. (2005). Results from the present study show that environments from May-October (warm season) that were "lapse rate starved" yielded shallower and weaker updrafts that were not supportive of lightning. In contrast, updraft depth and CAPE were sufficient for vigorous convection from November-April (cool season). However, cool season lightning was mainly confined to environments that possessed warmer boundary layer temperatures, which favored supercooled liquid water and graupel within the CRTZ. In addition, lightning was most probable, during both the warm and cool seasons, when favorable thermodynamic conditions were collocated with the most active portion of the synoptic flow regime.
\end{abstract}

\section{Introduction}

Marine lightning deaths consistently rank highest in the United States (Curran et al. 2000, Holle 2007). For example, Jensenius (2016) found that fishing-related activities resulted in more than four times as many lightning fatalities as golfing. Therefore, it is important for forecasters to provide their marine customers with the best possible lightning guidance. However, some marine environments produce lightning more readily than others. For example, the Gulf of Mexico (GOM) and northwestern Atlantic Ocean experience 16-32 strokes $\mathrm{km}^{-2} \mathrm{yr}^{-1}$, whereas $0-0.25$ occur over the northeastern Pacific Ocean (NEPAC) and Gulf of Alaska (GOA) (Fig. 1). These differences can, as a first approximation, be attributed to sea surface temperatures (SST) that are $\geq 10^{\circ} \mathrm{C}\left(\geq 18^{\circ} \mathrm{F}\right)$ warmer throughout the year for the GOM region compared to the NEPAC and GOA. Warmer SST values are positively correlated with larger convective available potential energy (CAPE) and thunderstorm development (Chambers et al. 2015). Despite the infrequency of thunderstorms relative to the GOM and northwestern Atlantic, lightning is regularly observed throughout the year offshore from the west coast of North America. Thus, forecasters must remain vigilant.

This study uses the results from Bright et al. (2005; hereafter B05) as a baseline for investigating the thermodynamic environment of thunderstorms over the NEPAC and GOA. B05 developed a physically based lightning prediction parameter that highlights environments supporting: 1) updraft speeds $\geq 10$ $\mathrm{m} \mathrm{s}^{-1}(\geq 19 \mathrm{kt})$ in the charge reversal temperature zone (hereafter CRTZ) , 2) the presence of updraft supercooled liquid water, and 3) updrafts that extend through the depth of the CRTZ.

When those ingredients are present, updrafts will be more likely to produce graupel. The non-inductive charge mechanism, possibly combined with the inductive charging mechanism (Kuettner et al. 1981), shows that graupel occurring within the CRTZ will collide with smaller ice particles, resulting in graupel acquiring a net negative charge as it descends through the updraft with time, while the positively charged smaller ice particles migrate toward the upper portions of the updraft (Reynolds et al. 1957). This process yields an increasing electric potential that makes lightning 


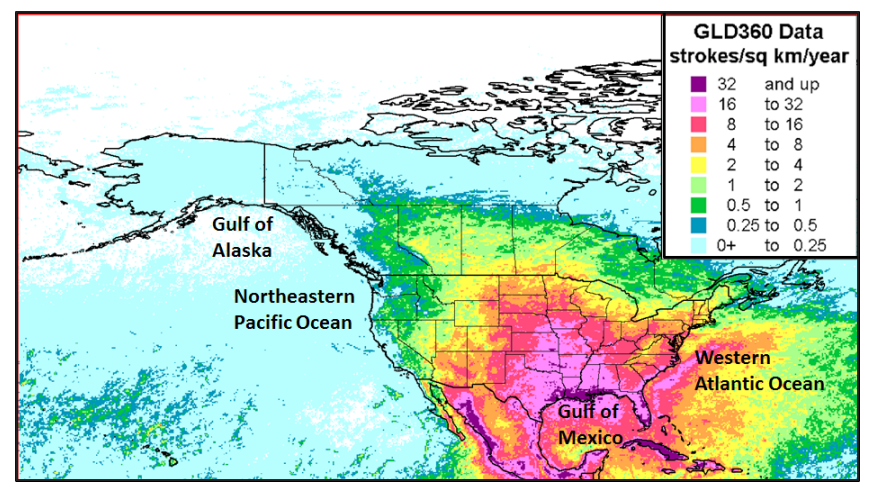

Figure 1. Global Lightning Dataset 360 (GLD360) lightning strikes $\left(\mathrm{km}^{-2} \mathrm{yr}^{-1}\right)$ from 2012 to 2015. Oceanic marine basins are annotated. Image courtesy of Vaisala. Click image for an external version; this applies to all tables and figures hereafter.

more probable.

B05 shows that a temperature at the lifting condensation level (LCL) $\geq-10^{\circ} \mathrm{C}\left(\geq 14^{\circ} \mathrm{F}\right)$ signals that sufficient supercooled liquid water will be present in the CRTZ updraft region for graupel growth and noninductive charging processes. Furthermore, the updraft must extend through the depth of the CRTZ to ensure that a mixture of supercooled liquid water and ice particles will be present for non-inductive charging. Thus, the equilibrium level (EL) temperature must be $\leq-20^{\circ} \mathrm{C}\left(\leq-4^{\circ} \mathrm{F}\right)$.

This article will compare and contrast the collocation of ingredients outlined above, and their utility for predicting lightning over the NEPAC and GOA. Attention also is given to the synoptic-scale environment in which these ingredients occur. The methods used for this study will be outlined in section 2 , results will be presented in section 3 , and the paper will be summarized in section 4 .

\section{Methodology}

All lightning and non-lightning (null) events analyzed in this study were recorded during operational forecast shifts at the National Weather Service in Juneau, Alaska. The Vaisala Global Lightning Dataset 360 (GLD360) was used in combination with satelliteobserved convective cloud structures to identify lightning or null occurrences. A lightning (null) event was defined as any convective element identified in satellite imagery associated with lightning (no lightning). The domain for this study was bounded to the south by $40^{\circ} \mathrm{N}$ latitude, to the west by $150^{\circ} \mathrm{W}$ longitude, and the northern and eastern boundary by the coast of North America (Fig. 2).

Because of its complete coverage across the study domain, the global forecast system (GFS) model, postprocessed to a $40-\mathrm{km}$ (25-mi) horizontal grid, and vertical resolution composed of 64 unequallyspaced sigma levels, was used to generate proximity soundings for most of the thermodynamic parameters associated with each lightning and null event. All lightning soundings were generated for the grid point coincident with maximum lightning activity, while null soundings were generated for the grid point coincident with the center of convective cloud development analyzed in satellite imagery. Model proximity soundings were modified at the surface using the AWIPS II version of SHARP (Hart et al. 1999) if the temperature or dewpoint exceeded $1{ }^{\circ} \mathrm{C}\left(1.8^{\circ} \mathrm{F}\right)$ when compared with the nearest fixed buoy station. After this step, the most unstable (MU) parcel was used to calculate parcelderived parameters. The current study deviates from the B05 method in one respect: total MUCAPE was used instead of MUCAPE in the CRTZ. This was done because qualitative analysis of individual soundings revealed that most of the free convective layer occurred within the CRTZ.

A model temperature and dewpoint error analysis was performed from the surface to $300 \mathrm{mb}$ by comparing GFS analysis soundings with 00 and 12 UTC RAOBs at Yakutat, Alaska (PAYA), Annette, Alaska (PANT), and Quillayute, Washington (KUIL). This analysis (Fig. 3) shows that average temperature errors were maximized at the surface $\left(0.31^{\circ} \mathrm{C}\right.$ or $\left.0.6^{\circ} \mathrm{F}\right)$ and $300 \mathrm{mb}\left(0.22^{\circ} \mathrm{C}\right.$ or $\left.0.4^{\circ} \mathrm{F}\right)$, and minimized between $925-700 \mathrm{mb}(-0.8$ to $0.3^{\circ} \mathrm{C}$, or -1.4 to $0.5^{\circ} \mathrm{F}$ ). Average dewpoint errors were larger, minimized at the surface $\left(0.5^{\circ} \mathrm{C}\right.$ or $\left.0.9^{\circ} \mathrm{F}\right)$, and then increasing almost linearly to $5.5^{\circ} \mathrm{C}\left(9.8^{\circ} \mathrm{F}\right)$ at 300 $\mathrm{mb}$.

Results in this paper span from August 2014 to March 2016. Lightning and null events were divided into a cool season category (CS; November-April), and a warm season category (WS; May-October). Events were further stratified based on where lightning (null) events occurred with respect to the synoptic pattern (Fig. 4), which was subjectively assessed using a combination of satellite imagery, as well as surface and upper-air analyses produced by the NOAA Ocean Prediction Center. This classification scheme reveals that $62 \%$ $(66 \%)$ of lightning (null) events occurred within a post

${ }^{1}$ The maximum updraft speed is estimated by taking the square root of CAPE. For example, an updraft speed of $10 \mathrm{~m} \mathrm{~s}^{-1}$ would be associated with a CAPE value of $100 \mathrm{~J} \mathrm{~kg}^{-1}$. See Schultz et al. (2000) for more on CAPE.

${ }^{2} \mathrm{The} \mathrm{CRTZ}$ resides in the 0 to $-20^{\circ} \mathrm{C}\left(32\right.$ to $\left.4^{\circ} \mathrm{F}\right)$ layer. 


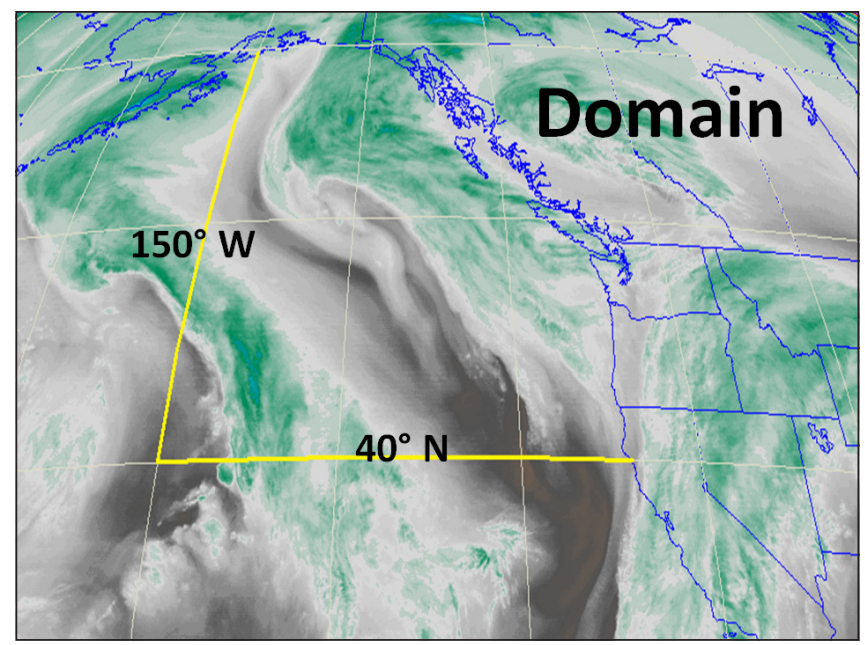

Figure 2. Area of study, bounded to the south by $40^{\circ}$ $\mathrm{N}$ latitude; to the west by $150^{\circ} \mathrm{W}$ longitude; and to the north and east by the west coast of North America.

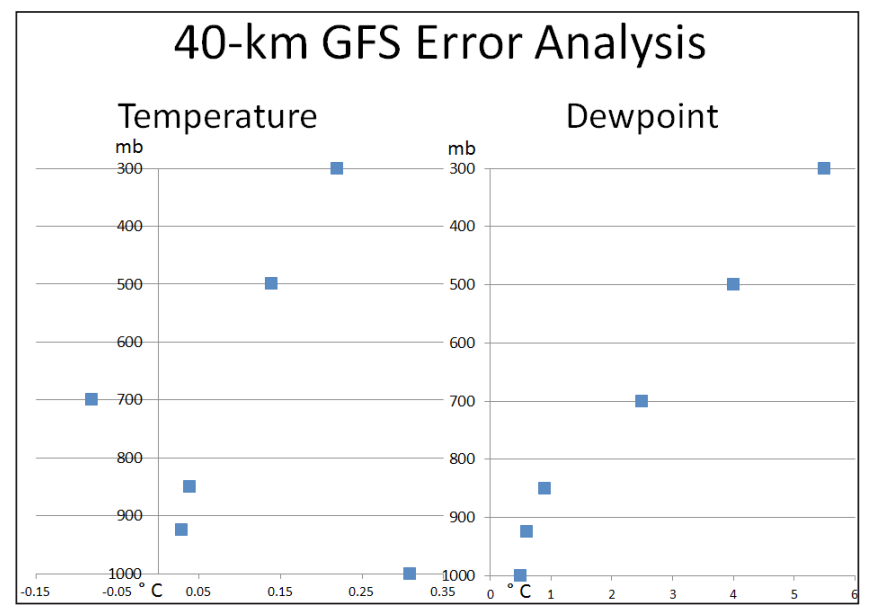

Figure 3. Mean temperature and dewpoint errors computed for 00 and 12 UTC, comparing differences between 40-km GFS analysis soundings and RAOB sites at Yakutat, AK (PAYA), Annette, AK (PANT), and Quillayute, WA (KUIL).

frontal air mass, 33\% (27\%) occurred along a frontal boundary, and $5 \%(7 \%)$ occurred within a pre-frontal warm conveyor belt. These surface classifications are combined with upper air patterns in section 3.b., that are defined as: 1) upper trough, 2) quasi-zonal upper jet, and 3) closed upper-low.

\section{Results}

\section{a. Thermodynamic parameters}

A summary of thermodynamic parameters is provided in Table 1, which shows that the boundary layer is warmer for lightning events, both in the WS and

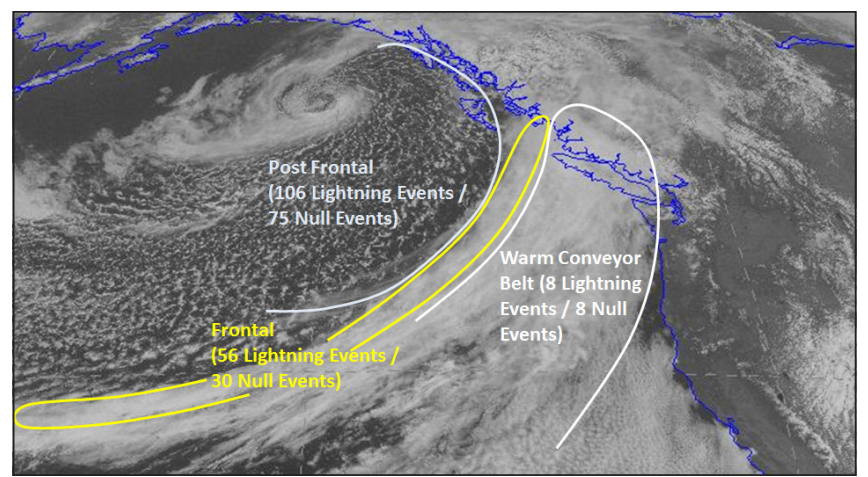

Figure 4. Annotated visible satellite image showing the three surface classifications used in the current study. The post-frontal regime is characterized by cellular convective cloud structures. The frontal regime is located along the elongated cloud band circled by the yellow line, and the pre-frontal warm conveyor belt is positioned to the right of the frontal cloud band.

CS. For example, average SST to $925-\mathrm{mb}$ temperatures are $2-3^{\circ} \mathrm{C}\left(3.6-5.4^{\circ} \mathrm{F}\right)$ warmer for lightning events compared to null events. On the other hand, mean temperatures at $500 \mathrm{mb}$ are roughly equivalent for both WS and CS lightning and null environments. Despite the similar midlevel temperatures, the warmer WS lightning boundary layer yields $925-600-\mathrm{mb}$ lapse rates that are $0.5^{\circ} \mathrm{C} \mathrm{km}^{-1}$ steeper compared to WS null events. The steeper lapse rates associated with WS lightning aid in average MUCAPE values that are $331 \mathrm{~J} \mathrm{~kg}^{-1}$ larger than WS null events. Furthermore, Fig. 5 shows that nearly 90\% of MUCAPE values for WS null environments reside below the 10th percentile of WS lightning values. For the CS, null MUCAPE values are larger than WS null values. However, interquartile comparisons of CS MUCAPE show that the lightning distribution is completely separated above the null distribution. These interquartile comparisons demonstrate that MUCAPE is effective in discriminating between lightning and null environments during both seasons.

Similar to MUCAPE, the EL temperature provides a strong means of discriminating between lightning and null environments during the WS. The mean EL temperature for WS lightning events is $-35^{\circ} \mathrm{C}\left(-31^{\circ} \mathrm{F}\right)$, and the mean null value is $-16^{\circ} \mathrm{C}\left(3.2^{\circ} \mathrm{F}\right)$. Furthermore, only $10 \%$ of the WS null events were associated with an EL temperature $\leq-20^{\circ} \mathrm{C}\left(-4^{\circ} \mathrm{F}\right)$, whereas the entire distribution of WS lightning EL temperatures were $<-20^{\circ} \mathrm{C}\left(-4^{\circ} \mathrm{F}\right)$ (Fig. 6). On the other hand, cool season EL temperatures show large interquartile overlap, and mean values are separated by only $3^{\circ} \mathrm{C}\left(5.4^{\circ} \mathrm{F}\right)$. We can 
Table 1. Mean thermodynamic parameters summarizing temperature and moisture associated with lightning and null environments during the warm and cool seasons. Precipitable water is abbreviated PW. Parameter data source is given in parenthesis.

\begin{tabular}{|c|c|c|c|c|}
\hline Parameter & $\begin{array}{c}\text { Lightning Warm Season } \\
\text { (mean) }\end{array}$ & $\begin{array}{l}\text { Null Warm Season } \\
\text { (mean) }\end{array}$ & $\begin{array}{l}\text { Lightning Cool Season } \\
\text { (mean) }\end{array}$ & Null Cool Season (mean) \\
\hline PW (GFS) & $2.4 \mathrm{~cm}(0.96 \mathrm{in})$ & $2.4 \mathrm{~cm}(0.96 \mathrm{in})$ & $1.3 \mathrm{~cm}(0.53 \mathrm{in})$ & $1.2 \mathrm{~cm}(0.47 \mathrm{in})$ \\
\hline SST (Satellite) & $15.7^{\circ} \mathrm{C}\left(60.3^{\circ} \mathrm{F}\right)$ & $13.1^{\circ} \mathrm{C}\left(55.6^{\circ} \mathrm{F}\right)$ & $11.3^{\circ} \mathrm{C}\left(52^{\circ} \mathrm{F}\right)$ & $8.6^{\circ} \mathrm{C}\left(47.5^{\circ} \mathrm{F}\right)$ \\
\hline 925-mb T (GFS) & $10.3^{\circ} \mathrm{C}\left(50.5^{\circ} \mathrm{F}\right)$ & $8.3^{\circ} \mathrm{C}\left(47^{\circ} \mathrm{F}\right)$ & $4.6^{\circ} \mathrm{C}\left(40.3^{\circ} \mathrm{F}\right)$ & $2.5^{\circ} \mathrm{C}\left(36.5^{\circ} \mathrm{F}\right)$ \\
\hline 500-mb T (GFS) & $-21^{\circ} \mathrm{C}\left(-5.8^{\circ} \mathrm{F}\right)$ & $-20.5^{\circ} \mathrm{C}\left(-4.9^{\circ} \mathrm{F}\right)$ & $-29.6^{\circ} \mathrm{C}\left(-21.3^{\circ} \mathrm{F}\right)$ & $-31.2^{\circ} \mathrm{C}\left(-24.2^{\circ} \mathrm{F}\right)$ \\
\hline $\begin{array}{l}\text { 925-600-mb Lapse Rate } \\
\text { (GFS) }\end{array}$ & $6.3^{\circ} \mathrm{C} \mathrm{km}^{-1}$ & $5.8^{\circ} \mathrm{C} \mathrm{km}^{-1}$ & $7.3^{\circ} \mathrm{C} \mathrm{km}^{-1}$ & $7.2^{\circ} \mathrm{C} \mathrm{km}^{-1}$ \\
\hline
\end{tabular}

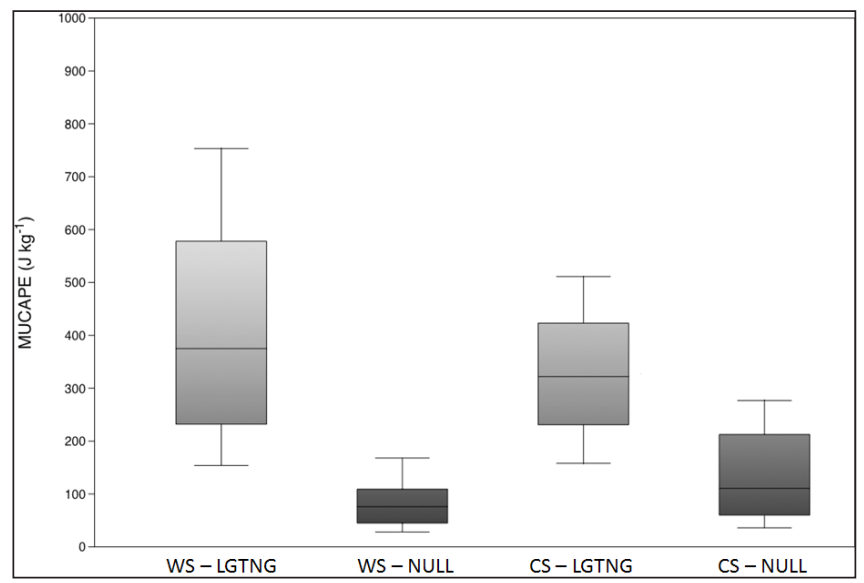

Figure 5. Box and whisker plot for MUCAPE $\left(\mathrm{J} \mathrm{kg}^{-1}\right)$. The boxed region represents the interquartile range, divided by the median. Whiskers represent 10 th and 90th percentiles. Abbreviations on the abscissa stand for lightning (LGTNG), warm season (WS), and cool season (CS).

thus infer that null convection in the WS is typically too shallow to support charge separation in the CRTZ; and though CS null convection does extend through the CRTZ, other factors preclude charge separation, which will be discussed next.

B05 highlighted the importance of supercooled liquid water aiding in graupel growth and charge separation within the CRTZ. More specifically, they found that supercooled liquid water in the updraft is more likely when the temperature at the LCL is $\geq-10^{\circ} \mathrm{C}$ $\left(\geq 14^{\circ} \mathrm{F}\right)$. Evaluation of LCL temperature for the current study shows that the lowest value associated with lightning was $-4^{\circ} \mathrm{C}\left(25^{\circ} \mathrm{F}\right)$, which occurred during the CS. However, the majority of CS lightning events $(90 \%)$ occurred with an LCL temperature $\geq 1^{\circ} \mathrm{C}\left(34^{\circ} \mathrm{F}\right)$, which is much larger than the $-10^{\circ} \mathrm{C}\left(14^{\circ} \mathrm{F}\right)$ threshold suggested by B05. Furthermore, Fig. 7 shows that the offset between CS lightning and null events supports the notion that lightning is more probable as the LCL temperature increases. For instance, $50 \%$ of the CS

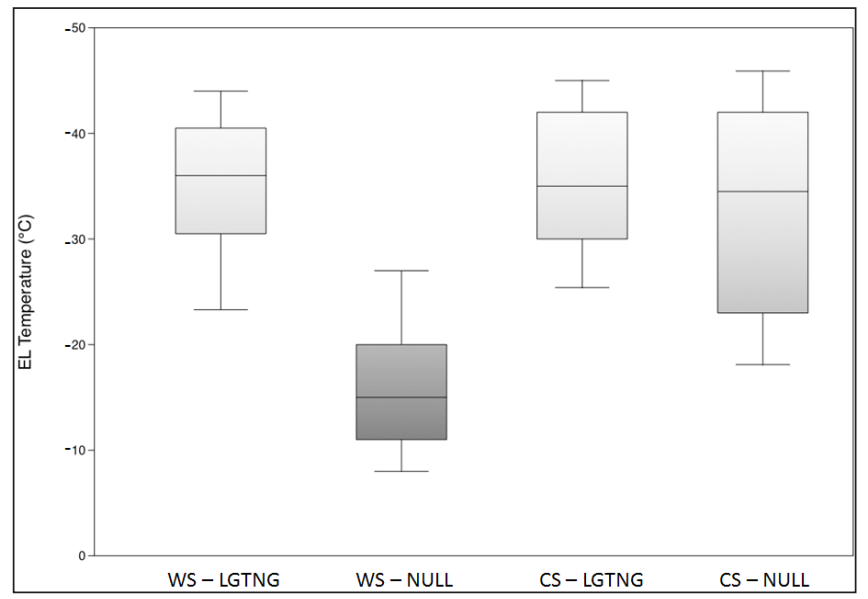

Figure 6. As in Fig. 5, except for equilibrium level (EL) temperature $\left({ }^{\circ} \mathrm{C}\right)$.

null events reside at or below $3^{\circ} \mathrm{C}\left(37^{\circ} \mathrm{F}\right)$, whereas the upper $75 \%$ of CS lightning events are warmer than $3^{\circ} \mathrm{C}$ $\left(37^{\circ} \mathrm{F}\right)$.

Warm cloud depth (WCD; height of the freezing level minus the height of the LCL) also is greater for CS lightning environments versus CS null environments, with the upper $75 \%$ of lightning events residing above $500 \mathrm{~m}(1640 \mathrm{ft})$, and the lower $50 \%$ of null events below $\sim 400 \mathrm{~m}$ (1312 ft) (Fig. 8). Using median values as a rough threshold, when the LCL temperature was below $3^{\circ} \mathrm{C}\left(37^{\circ} \mathrm{F}\right)$, and $\mathrm{WCD}$ was limited to $\leq 400 \mathrm{~m}(1312$ $\mathrm{ft}$ ), updrafts over the NEPAC and GOA were less likely to possess supercooled liquid water, and more likely to be glaciated with small ice crystals. Lightning was less probable as a result.

\section{b. Thermodynamic parameters within the synoptic} setting

Lightning and null events were matched with their associated surface and upper-level patterns. The three upper-level regimes were: 1) a short-wave trough, 2) a quasi-zonal jet, and 3) a closed low. These upperlevel patterns were collocated with one of three 


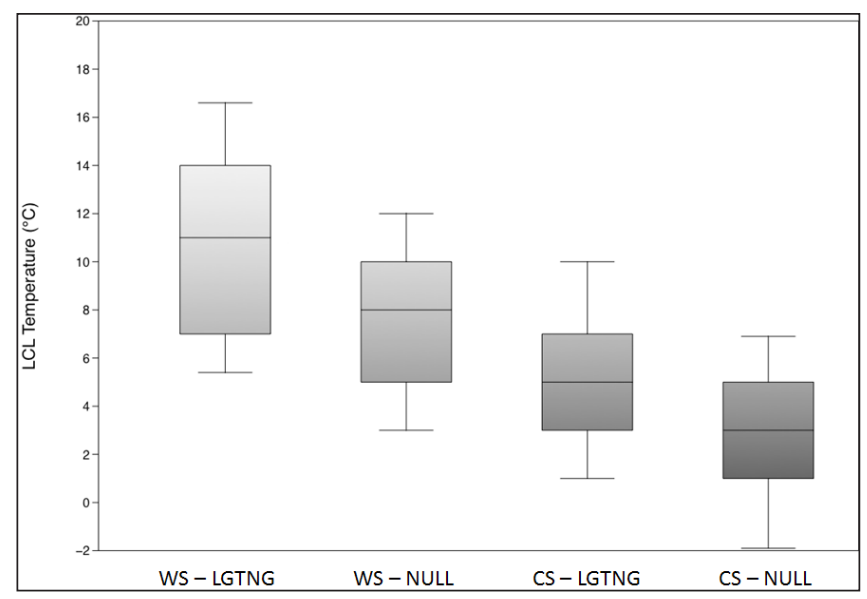

Figure 7. As in Fig. 5, except for lifting condensation level (LCL) temperature $\left({ }^{\circ} \mathrm{C}\right)$.

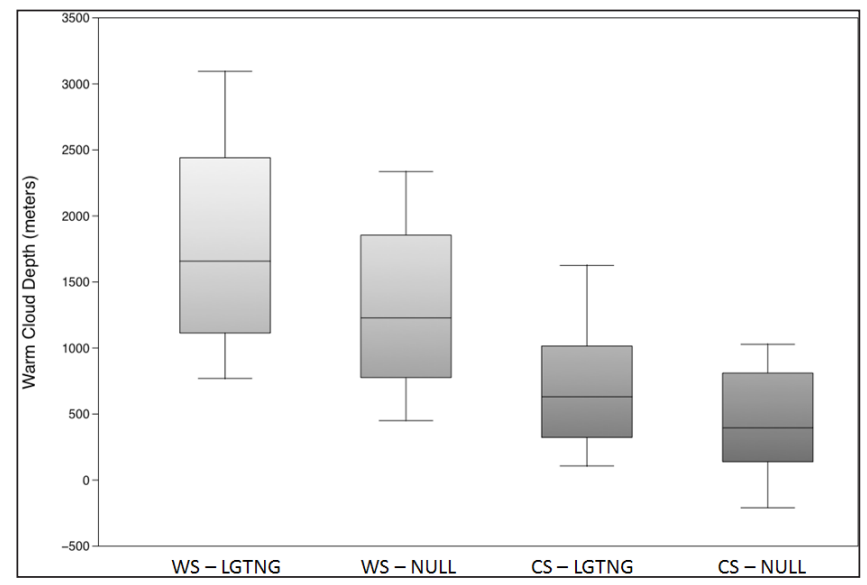

Figure 8. As in Fig. 5, except for warm cloud depth (meters).

surface patterns: 1) a post-frontal air mass, 2) a frontal boundary, or 3) a pre-frontal warm conveyor belt. Pattern combinations for lightning and null events are summarized in Table 2.

Roughly $61-64 \%$ of lightning and null events were 150-270 km (93-168 mi) from a progressive upperlevel short-wave trough, with convective activity focused along a surface frontal boundary, or within a post-frontal surface air mass (Fig. 9). These pattern combinations yielded the greatest average number of lightning strikes (174) among all of the patterns studied. However, the associated thermodynamic parameters were in the middle of the parameter distribution. For example, MUCAPE averaged $331 \mathrm{~J} \mathrm{~kg}^{-1}$, EL temperature $-35^{\circ} \mathrm{C}\left(-31^{\circ} \mathrm{F}\right)$, LCL temperature $9^{\circ} \mathrm{C}\left(48^{\circ} \mathrm{F}\right)$, and WCD $1487 \mathrm{~m}$ (4879 ft). Stronger forcing for ascent associated with a mobile upper disturbance combined with sufficient thermodynamics may partially explain why more strikes were observed.
A quasi-zonal upper-level jet was the second most common pattern associated with lightning production (Fig. 10), but unlike the shortwave pattern, the majority of lightning with a jet occurred almost exclusively within a post-frontal surface air mass. For the sake of clarity, upper jets may be coincident with an upper trough, or vice versa. However, the two patterns were distinguished in this study by identifying when the jet is embedded within the upper trough (upper trough pattern), versus when a smaller-scale trough is embedded within a jet (upper jet pattern). For example, subjective analysis of water vapor satellite imagery revealed that vigorous convection producing lightning was located an average of $210 \mathrm{~km}$ (130 mi) from smallscale upper-level waves embedded within a quasi-zonal jet.

The post-frontal air mass beneath the jet was associated with an average surface temperature of $12^{\circ} \mathrm{C}$ $\left(54^{\circ} \mathrm{F}\right)$, and a $925-600-\mathrm{mb}$ lapse rate of $7.2^{\circ} \mathrm{C} \mathrm{km}^{-1}$, which are in the cooler and steeper portion, respectively, of the lightning environment distribution. The steep lapse rate environment aided in an average MUCAPE value of $383 \mathrm{~J} \mathrm{~kg}^{-1}$. In addition, the cool boundary layer air mass associated with the post-frontal surface regime resulted in the lowest average LCL temperature; $7^{\circ} \mathrm{C}$ $\left(45^{\circ} \mathrm{F}\right)$ for lightning events, and $4^{\circ} \mathrm{C}\left(39^{\circ} \mathrm{F}\right)$ for null events.

No more than $4 \%$ of lightning and null events occurred within a pre-frontal warm conveyor belt (WCB). This environment was characterized by lifted parcel levels located between 950-800 mb, situated above a stable and saturated near-surface air mass. Boundary layer temperatures were $\sim 4^{\circ} \mathrm{C}\left(7^{\circ} \mathrm{F}\right)$ warmer than the other patterns; and average precipitable water values from 3 to $4 \mathrm{~cm}$ (1.2 to 1.6 in) were indicative of the moist subtropical air mass characteristic of the prefrontal WCB associated with many Pacific cyclones.

The upper-air pattern least likely to yield lightning was a closed low (Fig. 11). This pattern is accompanied by cold temperatures $\left(-20\right.$ to $-30^{\circ} \mathrm{C}\left[-4\right.$ to $\left.-22^{\circ} \mathrm{F}\right]$ at $500 \mathrm{mb}$ ), steep lapse rates $\left(6.6\right.$ to $7.2^{\circ} \mathrm{C} \mathrm{km}^{-1}$ in the 850 to 500 -mb layer), and MUCAPE values from 100 to 500 $\mathrm{J} \mathrm{kg}^{-1}$ that were supportive of widespread convective cells. However, the closed upper-low represents a fully occluded weakening cyclone devoid of significant forcing for ascent, as inferred from water vapor satellite imagery. The lack of augmented upward vertical motion arguably prevented convection from maturing to a stage supportive of lightning. This hypothesis is supported by all null events occurring close to the low center (0-64 km, or $0-40 \mathrm{mi})$, whereas the small handful 
Table 2. Ratio of upper-level and surface patterns for lightning events (left of divider), and null events (right of divider). Warm conveyor belt is abbreviated WCB.

\begin{tabular}{|c|c|c|c|}
\hline & Jet & Closed Low & Short-wave Trough \\
\hline Front & $4 \%(7 / 159) \mid 1 \%(1 / 108)$ & $4 \%(7 / 159) \mid 3 \%(3 / 108)$ & $25 \%(40 / 159) \mid 24 \%(26 / 108)$ \\
\hline Post-Frontal & $16 \%(26 / 159) \mid 3 \%(3 / 108)$ & $7 \%(11 / 159) \mid 29 \%(31 / 108)$ & $38 \%(60 / 159) \mid 33 \%(36 / 108)$ \\
\hline Pre-Frontal WCB & $4 \%(6 / 159) \mid 4 \%(4 / 108)$ & $0 \%(0 / 159) \mid 0 \%(0 / 108)$ & $1 \%(2 / 159) \mid 4 \%(4 / 108)$ \\
\hline
\end{tabular}

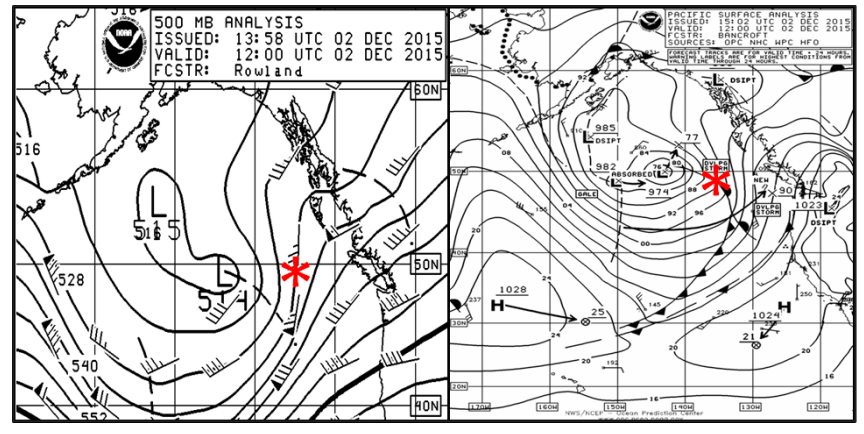

Figure 9. Example of a lightning event associated with an upper-level short-wave trough (left panel) and surface frontal boundary (right panel) valid at 12 UTC 2 December 2015. Lightning occurrence is marked by a red asterisk.

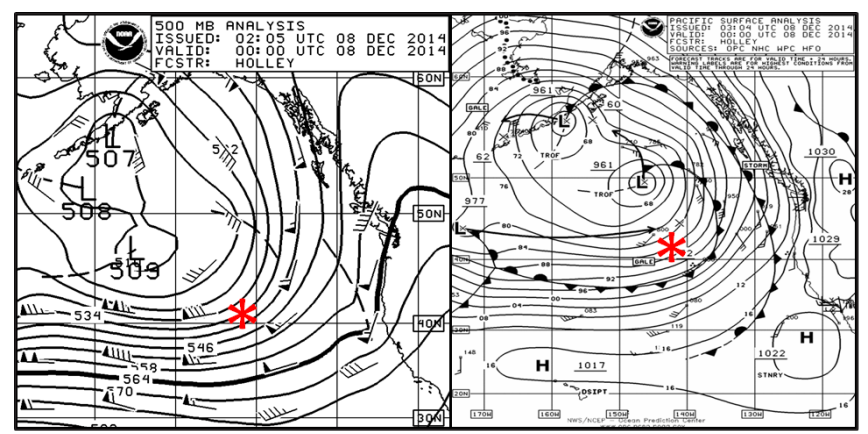

Figure 10. As in Fig. 9, except for an upper-level jet (left panel) and post-frontal surface air mass (right panel) valid at 00 UTC 8 December 2014.

of lightning events (4-7\%) occurred farther from the center (140-240 km, or 87-149 mi), where embedded upper disturbances were more likely to be entrained by the closed upper-low. Furthermore, null events near the center of the closed low were associated with surface and LCL temperatures that were on average $5^{\circ} \mathrm{C}\left(9^{\circ} \mathrm{F}\right)$ colder than lightning events, and MUCAPE values that were $300 \%$ smaller $\left(111 \mathrm{~J} \mathrm{~kg}^{-1}\right.$ versus $\left.447 \mathrm{~J} \mathrm{~kg}^{-1}\right)$. This provides additional evidence that the environment close to the center of an upper low was marginal for lightning.

\section{Summary}

Convection producing lightning over the NEPAC and GOA was most frequently observed when the active part of the synoptic flow regime was collocated with

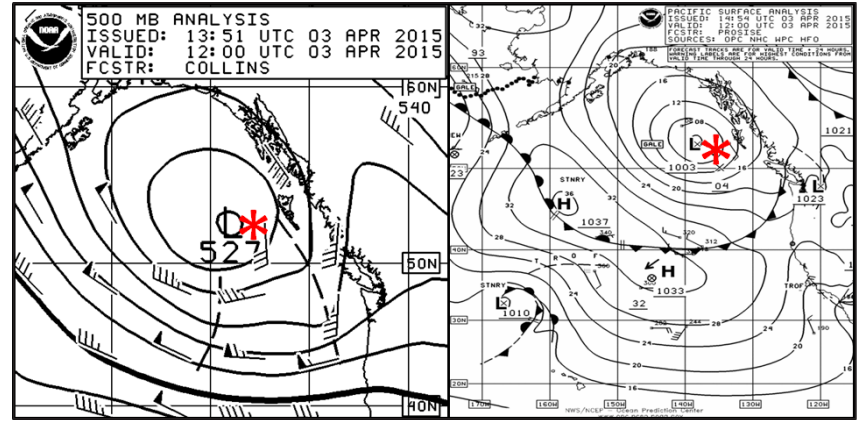

Figure 11. As in Fig. 9, except for a closed upper-level low (left panel) and occluded surface cyclone (right panel) valid at 12 UTC 3 April 2015.

thermodynamics supportive of graupel in the CRTZ. The two most common lightning producing upper-air patterns were a mobile short-wave trough and a quasizonal jet. In both cases, lightning occurrence was identified in water vapor satellite imagery near zones of augmented deep-layer ascent. Conversely, convection was less likely to produce lightning near a closed upperlevel low, where the weakening occluded cyclone was generally devoid of augmented ascent.

In all cases, the thermodynamic environment provided useful signals for identifying which synoptic regimes were more or less likely to yield lightning. During the warm season, convection associated with null events was shallow, with MUCAPE $<100 \mathrm{~J} \mathrm{~kg}^{-1}$ and EL temperatures $>-20^{\circ} \mathrm{C}\left(-4^{\circ} \mathrm{F}\right)$. The weak and shallow nature of warm season null convection prevented charge separation and lightning due to inadequate updraft depth through the CRTZ.

During the cool season, MUCAPE and EL temperatures were not the limiting factors. Instead, boundary layer temperatures played an important role in yielding sufficient supercooled liquid water for graupel production and storm electrification. Lightning environments were characterized by LCL temperatures greater than $\sim 3^{\circ} \mathrm{C}\left(5^{\circ} \mathrm{F}\right)$, and warm cloud depths $>400$ $\mathrm{m}(1312 \mathrm{ft})$. For LCL temperatures and warm cloud depths less than these values, updrafts were likely to be glaciated and devoid of large ice particles such as graupel. As a result, storm electrification and lightning were not probable. 
Acknowledgments. The author thanks Vaisala for granting permission for the use of figure 1. The author also thanks Doug Wesley and one anonymous reviewer for their valuable suggestions. Finally, the author is very grateful for the support provided by the management and staff at the National Weather Service in Juneau, Alaska, as well as the National Weather Service Alaska Region Headquarters.

\section{REFERENCES}

Bright, D. R., M. S. Wandishin, R. E. Jewell, and S. J. Weiss, 2005: A physically based parameter for lightning prediction and its calibration in ensemble forecasts. Preprints, Conf. on Meteorological Applications of Lightning Data, San Diego, CA, Amer. Meteor. Soc., CD-ROM, 4.3. [Available online at http://ai2-s2-pdfs.s3.amazonaws.com/ c21c/3b44544f3513118ad2885e9c502b8e43905e.pdf]

Chambers, C. R. S., G. B. Brassington, K. Walsh, and I. Simmonds, 2015: Sensitivity of the distribution of thunderstorms to sea surface temperatures in four Australian east coast lows. Meteorol. Atmos. Phys., 127, 499-517, CrossRef.

Curran, E. B., R. L. Holle, and R. E. Lopez, 2000: Lightning casualties and damages in the United States from 1959 to 1994. J. Climate, 13, 3448-3464, CrossRef.

Hart, J. A., J. Whistler, R. Lindsay, and M. Kay, 1999: NSHARP, version 3.10. Storm Prediction Center, National Centers for Environmental Prediction, Norman, OK, 33 pp.

Holle, R. L., 2007: Lightning-caused deaths and injuries in the vicinity of water bodies and vehicles. Intl. Conf. Lightning and Static Electricity, Aug. 28-31, Paris, France, paper IC07/PPRKM04, $15 \mathrm{pp}$.

Jensenius, J. S., Jr., 2016: A detailed analysis of lightning deaths in the United States from 2006 through 2015, Accessed 17 May 2016, [Available online at http://www. lightningsafety.noaa.gov/fatalities/analysis06-14.pdf].

Kuettner, J. P., J. D. Sartor, and Z. Levin, 1981: Thunderstorm electrification-Inductive or non-inductive? J. Atmos. Sci., 38, 2740-2484, CrossRef.

Reynolds, S. E., M. Brook, and M. F. Gourley, 1957: Thunderstorm charge separation. J. Meteor., 14, 426-436, CrossRef.

Schultz, D. M., P. N. Schumacher, and C. A. Doswell III, 2000: The intricacies of instabilities. Mon. Wea. Rev., 128, 4143-4148, CrossRef. 